\title{
Uporaba dobrih praks za spodbujanje socialno-emocionalnega razvoja pri otrocih prvega starostnega obdobja v vrtcu
}

\author{
Marta Licardo \\ Univerza v Mariboru \\ marta.licardo@um.si \\ Metka Purgaj \\ Vrtec Sladki Vrh \\ metka.purgaj@gmail.com
}

\begin{abstract}
V prispevku je predstavljen pomen uporabe dobrih praks za spodbujanje socialno-emocionalnega razvoja pri otrocih starosti od enega do treh let. Namen raziskave je bil ugotoviti, kakšna je ocena strokovnih delavcev glede pomembnosti socialno-emocionalnega področja v primerjavi z drugimi področji razvoja (npr. estetski razvoj, moralno-etični razvoj, kognitivni razvoj, motorika), kakšna je ocena pomembnosti področja družba $v$ primerjavi z drugimi področji dejavnosti v kurikulumu (umetnost, naravoslovje, jezik, gibanje, matematika) ter ali pri uporabi dobrih praks za to področje obstajajo razlike med homogenimi in heterogenimi skupinami. Rezultati kažejo, da strokovni delavci, ki delajo z otroki v prvem starostnem obdobju, socialno-emocionalno področje uvrščajo med najpomembnejša področja razvoja. Rezultati kažejo tudi, da se $v$ homogenih skupinah dobre prakse za otrokov socialno-emocionalni razvoj uporabljajo pogosteje kot $v$ heterogenih skupinah prvega starostnega obdobja ter da strokovni delavci najpogosteje uporabljajo tiste prakse, ki so del vsakodnevnih interakcij, manj pogosto pa uporabljajo prakse, za katere je potrebno vsaj delno načrtovanje ali poznavanje specifičnih strategij.
\end{abstract}

Ključne besede: socialno-emocionalni razvoj, metode, dobre prakse, zgodnje otroštvo, predšolska vzgoja

\section{Uvod}

Dobre prakse za spodbujanje socialno-emocionalnega razvoja otrok v zgodnjem otroštvu so lahko vezane na postopke, dejavnosti, aktivnosti, metode ali procese, ki prinašajo najboljše rezultate in temeljijo na dokazih raziskav ali izkušenj. Socialno-emocionalni razvoj in njegovo spodbujanje sta pomemben dejavnik, ki vpliva na celosten in daljnosežen razvoj otroka. Otroci, ki imajo razvite socialno-emocionalne veščine, lažje razumejo, izražajo in 
regulirajo lastna dejanja in čustvovanja (Woolfolk 2002). Učenje socialnoemocionalnih veščin ima lahko takojšnje in neposredne učinke, saj se otrok nauči, kako se sporazumevati z vrstniki in drugimi bližnjimi osebami, hitreje in učinkoviteje lahko sodeluje pri učenju novega, doživlja več pozitivnih povratnih informacij, kar ugodno vpliva na njegovo samopodobo in dobro počutje v primerjavi z otroki, ki imajo socialno-emocionalne veščine slabše razvite (Goodman idr. 2015). Raziskave kažejo, da obstajajo pozitivne korelacije med razvojem socialno-emocionalnih veščin v zgodnjem otroštvu in pripravljenostjo na vstop v šolo, šolskim uspehom in razvojem kognicije (Durlak idr. 2011; Elias idr., 1997; DiPerna in Elliot 2002).

Od strokovnih delavcev $v$ vrtcih se pričakuje, da bodo podpirali otrokov razvoj na vseh področjih, pri čemer ima socialno-emocionalno področje izjemen pomen, saj se $v$ zgodnjem obdobju oblikujejo temelji za razvoj otrokovih veščin na tem področju, ki jih je v kasnejših obdobjih težje oblikovati ali preoblikovati. Strokovni delavci v vrtcih naj bi torej spodbujali otroke k medsebojni komunikaciji, skrbeli naj bi za primerno dobro čustveno in socialno počutje otrok, razvoj zavedanja samega sebe, razvoj samoregulacije v skladu z razvojno stopnjo, razvoj pozitivne samopodobe itd., kar so vse pomembni prediktorji otrokovega uspeha in dobrega počutja (Petty 2016; DiPerna in Elliot 2002). Skrb za omenjena področja naj ne bi bila le del vsakodnevnih rutin in komunikacije, temveč bi morala biti tudi del premišljenih načrtovanih dejavnosti izvedbenega kurikuluma, kjer se otroci učijo socialno-emocionalnih veščin in kjer se spremljajo razvojni mejniki za to področje ter kjer vzgojitelj zna in zmore ustrezno ukrepati, kadar pri posameznem otroku zazna odstopanja.

Raziskave o uporabi dobrih praks za razvoj socialno-emocionalnih veščin v zgodnjem otroštvu v vrtcu kažejo, da je vrtčevsko okolje prvo socialno okolje otroka zunaj družine in s tem pomembno polje njegovih socialnih in emocionalnih izkušenj, kjer izkazuje in preizkuša svoje veščine (Phillips, McCartney in Sussman 2006). Prav tako otroci v tem obdobju doživljajo hitre in pomembne spremembe, ki vključujejo učenje jezika ter razvoj možganov, ki sta oba ključnega pomena za učenje komunikacijskih veščin, socialnih veščin, razumevanja čustev, samoregulacije ipd. (Thompson in Lagattuta 2006; Blair 2002). Zato je v vrtcu pomembno zagotoviti varno, sprejemajoče okolje, $v$ katerem se vzpostavljajo in ohranjajo prijetni odnosi med otroki in odraslimi, kjer se uporabljajo dobre prakse $v$ vsakodnevnih interakcijah in kjer znajo odrasli po potrebi tudi strokovno intervenirati v primeru čustvenih ali vedenjskih težav otrok (Hyson 2004). Ob tem pa je treba tudi načrtovati dejavnosti, ki vključujejo igre, branje in druge vodene dejavnosti za učenje socialno-emocionalnih 
veščin (Cohen 2001). Namreč, različni programi za učenje slednjih v zgodnjem otroštvu kažejo mnoge pozitivne učinke (Payton idr. 2008; Joseph in Strain 2003; Pianta idr. 2009).

Namen pričujoče raziskave je bil preveriti, kako strokovni delavci, ki imajo v skupini otroke od 1 do 3 let starosti, ocenjujejo socialno-emocionalno področje ter kako pogosto izvajajo posamezne dobre prakse. Postavke, ki se nanašajo na dobre prakse, vključujejo oceno strokovnih delavcev o pogostosti različnih vsakodnevnih interakcij in pogostosti izvedbe različnih dejavnosti. Preverjali smo tudi, ali obstajajo razlike pri uporabi dobrih praks glede na skupino (homogena/heterogena). Z raziskovalnimi vprašanji smo želeli osvetlili pojmovanja strokovnih delavcev o socialno-emocionalnem razvoju otrok v primerjavi s področji razvoja in področji dejavnosti ter preveriti, katere dobre prakse so najpogosteje izvajane.

\section{Metodologija}

\section{Vzorec}

Rezultati, ki so predstavljeni v prispevku, so del večje raziskave, v kateri je sodelovalo 209 strokovnih delavcev iz različnih regij v Sloveniji, od teh jih je 121 delalo $z$ otroki drugega starostnega obdobja in $88 \mathrm{z}$ otroki prvega starostnega obdobja. Ker je $v$ glavni del rezultatov zajeta samo populacija strokovnih delavcev, ki dela z otroki prvega starostnega obdobja, v nadaljevanju podrobneje predstavljamo ta vzorec. V vzorcu strokovnih delavcev $(n=88)$, ki delajo z otroki prvega starostnega obdobja, je bila starostna struktura precej enakomerno razpršena, 22,7\% je bilo starih 51 ali več let, 9,1\% je bilo starih med 46 in 50 let, 10,2\% je bilo starih med 41 in 45 let, 17,0\% je bilo starih od 36 do 40 let, $19,3 \%$ je bilo starih od 30 do 35 let, $18,2 \%$ je bilo starih od 24 do 29 let in 3,4\% je bilo starih med 18 in 23 let. 40,9\% strokovnih delavcev je imelo zaključeno srednješolsko izobrazbo, $38,6 \%$ je imelo zaključeno višjo ali visoko izobrazbo, 19,3 je imelo zaključeno univerzitetno izobrazbo in le 1,1\% je imelo končan magisterij ali več. V vzorcu je imela tretjina (29,5\%) 6 do 10 let delovnih izkušenj, 23,9\% jih je imelo do 5 let delovnih izkušenj, 20,5\% jih je imelo 26 ali več let delovnih izkušenj, 12,5\% jih je imelo 11 do 15 let delovnih izkušenj, 9,1\% jih je imelo 21 do 25 let delovnih izkušenj in 4,5\% jih je imelo 16 do 20 let delovnih izkušenj. 52,3\% strokovnih delavcev je bilo na delovnem mestu pomočnika vzgojitelja, $47,7 \%$ pa na delovnem mestu vzgojitelja. Večina $(87,5 \%)$ je imela v skupini 9 do 14 otrok, 2,3\% jih je imelo manj kot 9 otrok, $10,2 \%$ je bilo takih, ki so imeli več kot 15 otrok, ker so imeli heterogene ali kombinirane skupine. Več kot dve tretjini $(67,2 \%)$ strokovnih delavcev je bilo vključenih v izobraževanje o socialno-emocionalnem razvoju otrok pred 
manj kot dvema letoma, le 3,4\% jih je takšno izobraževanje imelo pred več kot 10 leti in $19,3 \%$ pred več kot 5 leti.

\section{Instrumentarij}

Uporabili smo anketni vprašalnik, ki je nastal za potrebe te raziskave in vsebuje vprašanja zaprtega tipa. Postavke v vprašalniku smo oblikovali na podlagi strokovne literature (Ward Platt 2006; Ivić, Novak in Ašković 2002; Early Learning Guidelines for Children Birth to Age Three 2015; Marjanovič Umek idr. 2004; Licardo 2016). Vprašalnik je sestavljen iz več sklopov: (a) vprašanja o demografskih podatkih; (b) vprašanja o pomembnosti posameznih področij razvoja in področij dejavnosti za otrokov nadaljnji razvoj in uspešnost v življenju; (c) vprašanja o poznavanju in spodbujanju socialnoemocionalnega razvoja; (č) vprašanja o izvajanju aktivnosti, ki spodbujajo socialno-emocionalni razvoj v prvem starostnem obdobju, in vprašanja o izvajanju aktivnosti, ki spodbujajo socialno-emocionalni razvoj v drugem starostnem obdobju. V sklopu a smo uporabili zaprti tip vprašanj, kjer je možen le en odgovor. V sklopu b smo uporabili ocenjevalno lestvico Likertovega tipa od 1 do 5 ( 1 - ni pomembno, 2 - malo pomembno, 3 - srednje pomembno, 4 - precej pomembno, 5 - zelo pomembno). Sklop c je prav tako sestavljen z ocenjevalno lestvico Likertovega tipa od 1 do 5 (1 - sploh se ne strinjam, 2 - se ne strinjam, 3 - ne morem se opredeliti, 4 - se strinjam, 5 - popolnoma se strinjam). Tudi pri zadnjem d sklopu je uporabljena Likertova ocenjevalna lestvica d 1 do 5 ( 1 - nikoli, 2 - redko, 3 - srednje pogosto, 4 - pogosto, 5 vedno). Veljavnost anketnega vprašalnika smo preverili s poskusnim reševanjem ankete. Po končani pilotski izvedbi smo opustili ali spremenili dvoumna ali nejasna vprašanja. Zanesljivost smo preverjali s Cronbachovim koeficientom alfa. Koeficient zanesljivosti pri oceni pomembnosti posameznih področij razvoja in področij dejavnosti za otrokov nadaljnji razvoj ter uspešnost v življenju za lestvico b je o,93. Koeficient zanesljivosti pri samooceni poznavanja in spodbujanja socialno-emocionalnega razvoja za lestvico c je o,82 in pri samooceni aktivnosti, ki spodbujajo socialno-emocionalni razvoj v prvem starostnem obdobju, za lestvico d je o,84. Koeficienti dokazujejo ustrezno raven notranje konsistentnosti lestvic (DeVellis 2003).

\section{Postopki zbiranja podatkov in analize}

Anketne vprašalnike smo poslali v vrtce po Sloveniji, kjer so jih izpolnjevali vzgojitelji in pomočniki vzgojiteljev. Podatke smo zbirali aprila 2017 s spletno anketo, nato pa smo vprašalnike še natisnili in jih maja ter junija 2017 razdelili v tiskani obliki, ker je bila pri zbiranju podatkov s spletno anketo odzivnost 
premajhna. Tiskane vprašalnike smo nato razdelili po vrtcih $v$ različnih regijah. Za primerjavo področij razvoja in področij dejavnosti pri strokovnih delavcih, ki delajo z otroki v prvem in drugem starostnem obdobju, smo analizirali deskriptivno statistiko $(\min , \max , M, S D)$. S $t$-testom za neodvisne vzorce smo preverjali tudi razlike glede na skupine (homogene nasproti heterogenim skupinam).

V prispevku navajamo le pomembnejše rezultate za prvo starostno obdobje: (a) primerjavo ocen pomembnosti socialnega in emocionalnega področja glede na druga področja razvoja, (b) primerjavo ocen pomembnosti področja družba v primerjavi z drugimi področji dejavnosti, (c) pogostost uporabe dobrih praks za spodbujanje socialno-emocionalnega razvoja v prvem starostnem obdobju in (č) razlike glede na heterogene in homogene skupine pri uporabi dobrih praks za socialno-emocionalni razvoj v prvem starostnem obdobju.

\section{Rezultati}

V nadaljevanju predstavljamo sklope posameznih rezultatov. $V$ vseh rezultatih so zajeti strokovni delavci, ki delajo $\mathrm{v}$ vrtcih z otroki, starimi od 1 do 3 let, v sklopu a in b pa tudi tisti, ki delajo $z$ otroki, starimi od 3 do 6 let.

\section{(a) Primerjava ocen pomembnosti socialnega in emocionalnega področja glede na druga področja razvoja}

Na sliki 1 so prikazane povprečne ocene strokovnih delavcev glede pomembnosti posameznih področij razvoja za otrokov optimalni razvoj. Področja razvoja smo povzeli po Kurikulumu za vrtce (Ministrstvo za šolstvo in šport 1999). Ocene so razdeljene $v$ dve skupini: na levi so povprečja ocen strokovnih delavcev, ki delajo $z$ otroki starosti od 1 do 3 let ( $v$ nadaljevanju 1. SO), na desni pa povprečja ocen strokovnih delavcev, ki delajo $z$ otroki starosti od 3 do 6 let (v nadaljevanju 2. SO).

Iz rezultatov lahko razberemo, da so vse povprečne vrednosti pričakovano precej visoke. Po ocenah za 1. SO so najpomembnejša tri področja, jezik in govor $(M=4,84 ; S D=0,39)$, socialno področje $(M=4,82 ; S D=0,41)$ in emocionalno področje $(M=4,82 ; S D=0,41)$, pri čemer so za socialno in emocionalno področje ocene za 1. SO popolnoma izenačene. Temu sledijo področja motorike $(M=4,72 ; S D=0,50)$, kognicije $(M=4,51 ; S D=0,66)$, motivacije $(M=$ $4,50 ; S D=0,71)$, moralno-etičnega razvoja $(M=4,48 ; S D=0,71)$ in kot najmanj pomemben je ocenjen estetski razvoj $(M=3,90 ; S D=0,87)$. Pri preverjanju statistično značilnih razlik med ocenami glede na SO smo ugotovili, da statistično pomembnih razlik ni (motorika: $t(207)=-0,07 ; p=0,94$; socialno po- 


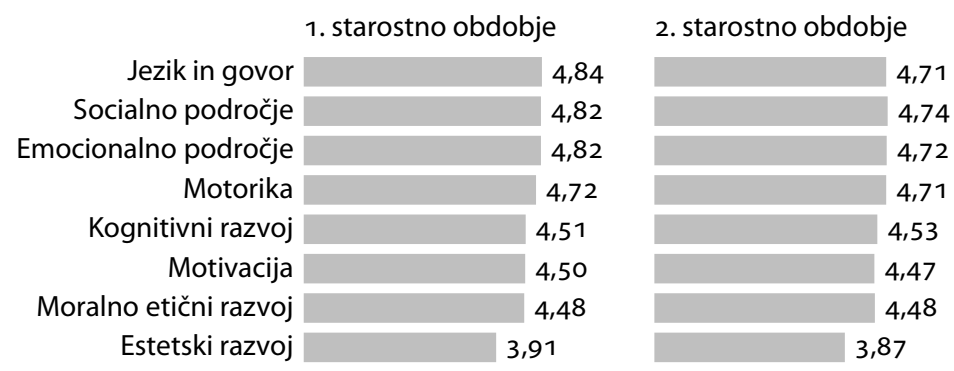

Slika 1 Ocene strokovnih delavcev, ki delajo v 1. in 2. starostnem obdobju, o pomembnosti posameznih področij razvoja (povprečna vrednost na lestvici od 1 do 5 )

dročje: $t(207)=-1,20 ; p=0,22$; emocionalno področje: $t(207)=-1,34 ; p=0,18$; estetski razvoj: $t(207)=-0,35 ; p=0,73$; motivacija: $t(207)=-0,28 ; p=0,77$; moralno-etični razvoj: $t(207)=0,02 ; p=0,98$; kognitivni razvoj: $t(207)=0,18$; $p=0,85)$.

Če rezultate za 1. SO primerjamo z rezultati za 2., lahko sklenemo, da sta socialno in emocionalno področje $v$ obeh obdobjih med najpomembnejšimi področji, pri čemer strokovni delavci nekoliko višje povprečne vrednosti ocen pripisujejo $v 1$. SO.

V nadaljevanju smo preverjali, kako strokovni delavci ocenjujejo pomembnost področja dejavnosti družba v primerjavi s preostalimi področji, saj vodene dejavnosti glede učenja in poučevanja socialno-emocionalnega razvoja sodijo na to področje (Ministrstvo za šolstvo in šport 1999).

\section{(b) Primerjava ocen pomembnosti področja družba v primerjavi z drugimi področji dejavnosti}

Rezultati ocen pomembnosti po področjih kažejo, da strokovni delavci v 1. SO presenetljivo kot najpomembnejše ocenjujejo področje matematike $(M$ $=4,27 ; S D=0,78)$, temu sledijo gibanje $(M=4,24 ; S D=0,74)$, jezik $(M=4,20$; $S D=0,74)$, družba $(M=4,12 ; S D=0,78)$, naravoslovje $(M=4,06 ; S D=0,75)$ in umetnost $(M=4,04 ; S D=0,80)$. Vse povprečne ocene so pričakovano precej visoke, kljub temu pa lahko razberemo, da družba kot področje ni prepoznano kot najpomembnejše, kar bi bilo v skladu z visokimi ocenami za področja razvoja. Domnevamo lahko, da morda strokovni delavci 1. SO v svojih pojmovanjih socialno-emocionalnega področja ne ocenjujeo kot nekaj, česar se otrok kar najbolje uči predvsem skozi načrtovane in vodene dejavnosti na področju družba.

Če primerjamo rezultate med 1. in 2. SO, lahko ugotovimo, da v 2. SO strokovni delavci kot najpomembnejše ocenjujejo področje gibanja $(M=4,38$; 


\begin{tabular}{r|rc}
\multicolumn{2}{|c}{ 1. starostno obdobje } & 2. starostno obdobje \\
Matematika & 4,27 & 4,19 \\
Gibanje & 4,24 & 4,38 \\
Jezik & 4,20 & 4,07 \\
Družba & 4,19 & 4,19 \\
Naravoslovje & 4,07 & 4,04 \\
Umetnost & 4,05 & 4,07
\end{tabular}

Slika 2 Ocene strokovnih delavcev, ki delajo v 1. in 2. starostnem obdobju, o pomembnosti posameznih področij dejavnosti po Kurikulumu za vrtce (Ministrstvo za šolstvo in šport 1999) (povprečna vrednost na lestvici od 1 do 5)

$S D=0,78)$, kot enako pomembno pa ocenjujejo področji družba $(M=4,12$; $S D=0,72)$ in matematika $(M=4,12 ; S D=0,75)$. Pri preverjanju razlik povprečij med 1. in 2 . SO s $t$-testom za neodvisne vzorce smo ugotovili, da statistično pomembnih razlik med skupinama ni, nakazuje se le tendenca razlik pri področju jezika $(t(207)=-1,81 ; p=0,07)$, kjer strokovni delavci v 1. SO temu področju pripisujejo večji pomen kot tisti v 2 . SO.

Sledi analiza rezultatov glede razlik pri uporabi dobrih praks za socialnoemocionalni razvoj v prvem starostnem obdobju.

\section{(c) Pogostost uporabe dobrih praks za spodbujanje socialno-emocionalnega razvoja v prvem starostnem obdobju}

Podatki kažejo, da strokovni delavci v prvem starostnem obdobju najpogosteje vzpostavljajo prijeten in ljubeč odnos z otrokom $(M=4,73 ; S D=0,50)$, vzpostavljajo primerno interakcijo pri prihodih in odhodih otrok $(M=4,60$; $S D=0,52)$, so dosledni pri uveljavljanju meja in pravil, primernih starosti $(M=$ $4,47 ; S D=0,72)$, ter se odzivajo s poslušanjem, kadar želi otrok povedati kaj o sebi $(M=4,36 ; S D=0,83)$. Manj pogosto spodbujajo otroke, da izražajo čustva na različne načine $(M=3,88 ; S D=0,76)$, manj pogosto tolažijo otroka, kadar je vznemirjen in pri tem uporabljajo metodo potrjevanja čustev $(M=3,74 ; S D$ $=1,09$ ), ter manj pogosto namenjajo čas branju $z$ enim ali dvema otrokoma $(M=3,59 ; S D=0,85)$.

Iz rezultatov lahko razberemo, da strokovni delavci pogosteje uporabljajo dobre prakse, ki so del vsakodnevnih interakcij z otroki in zanje ni potrebno posebno načrtovanje, kot so prihodi in odhodi, vsakodnevne interakcija ter komunikacija v odnosu z otrokom, uveljavljanje meja in pravil. Manj pogosto pa izvajajo dobre prakse, za katere je potrebno vsaj delno načrtovanje (npr. skupno branje) ali pa celostno načrtovanje, kot je spodbujanje izražanje čustev skozi glasbo, ples ali likovno umetnost. Manj pogosto uporabljajo tudi strategijo potrjevanja čustev. 
Preglednica 1 Uporaba dobrih praks za spodbujanje socialno-emocionalnega razvoja v 1. starostnem obdobju

\begin{tabular}{|c|c|c|}
\hline Spremenljivke & $M$ & $S D$ \\
\hline $\begin{array}{l}\text { Vzpostavljam prijeten in ljubeč odnos z otrokom, kadar si otrok zaželi } \\
\text { bližino odraslega. }\end{array}$ & 4,73 & 0,50 \\
\hline $\begin{array}{l}\text { Pri odhodu otroka domov mu pojasnim, da se kmalu vidimo, in } \\
\text { vzpostavim primerno interakcijo, npr. pomaham, pozdravim. }\end{array}$ & 4,60 & 0,52 \\
\hline $\begin{array}{l}\text { Sem dosledna pri uveljavljanju meja in pravil, ki so primerna starosti in } \\
\text { realnim pričakovanjem. }\end{array}$ & 4,47 & 0,72 \\
\hline Otroka poslušam in se nanj odzovem, ko mi poskuša povedati kaj o sebi. & 4,36 & 0,83 \\
\hline Poudarjam pomen deljenja igrač in stvari. & 4,30 & 0,76 \\
\hline Kadar je otrok vznemirjen, ga potolažim in ubesediva doživljanje čustev. & 4,22 & 0,76 \\
\hline Zagotovim čas za domišljijsko in simbolno igro. & 4,18 & 0,71 \\
\hline Otrokom ponudim igrače, pri katerih sta za igro potrebna dva ali več otrok. & 4,14 & 0,67 \\
\hline $\begin{array}{l}\text { Z otroki se pogovarjam o čustvih in tem, da je v redu, če doživlja različna } \\
\text { čustva. }\end{array}$ & 4,02 & 0,79 \\
\hline $\begin{array}{l}\text { Opazujem izražanje otrokovih čustev in ustrezno ukrepam, preden } \\
\text { izbruhnejo negativna čustva. }\end{array}$ & 4,00 & 0,69 \\
\hline $\begin{array}{l}\text { Otroke spodbujam, da čustva izražajo na različne načine, npr. skozi } \\
\text { likovno umetnost, ples, glasbo, domišljijsko igro. }\end{array}$ & 3,88 & 0,76 \\
\hline $\begin{array}{l}\text { Uporabljam slike otrok in njihovih bližnjih, kadar se pogovarjam o } \\
\text { konceptih, vezanih na zavedanje sebe in drugih. }\end{array}$ & 3,81 & 0,93 \\
\hline $\begin{array}{l}\text { Tolažim otroka, kadar je vznemirjen, tako da izgovarjam čustva, ki jih } \\
\text { otrok doživlja, npr. »ezen si«. }\end{array}$ & 3,74 & 1,09 \\
\hline Vsak dan namenim čas branju skupaj z dvema, tremi otroki. & 3,59 & 0,85 \\
\hline
\end{tabular}

(d) Razlike glede na heterogene in homogene skupine pri uporabi dobrih praks za socialno-emocionalni razvoj v prvem starostnem obdobju

Podatki glede razlik $v$ uporabi metod za socialno-emocionalni razvoj med heterogenimi in homogenimi skupinami v prvem starostnem obdobju kažejo, da strokovni delavci, ki delajo $v$ homogenih skupinah, statistično značilno večkrat uporabljajo socialno-emocionalno interakcijo $z$ otrokom pri odhodu domov kot tisti, ki delajo $v$ heterogenih skupinah $(t(83)=2,34 ; p=0,02)$, prav tako so doslednejši pri uveljavljanju meja in pravil, primernih starosti in realnim pričakovanjem $(t(83)=2,40 ; p=0,02)$, pogosteje poslušajo otroka in se nanj odzovejo, kadar poskuša povedati kaj o sebi $(t(83)=4,05 ; p=0,00)$, pogosteje z njim vzpostavljajo prijeten in ljubeč odnos $(t(83)=3,33 ; p=0,00)$, pogosteje ga potolažijo, kadar je vznemirjen, in ubesedijo doživljanje čustev $(t(83)=1,98 ; p=0,05)$ ter pogosteje poudarjajo pomen deljenja igrač ( $t(82)$ $=2,08 ; p=0,04)$.

Izmed petnajst navedenih postavk za spodbujanje socialno-emocionalne- 


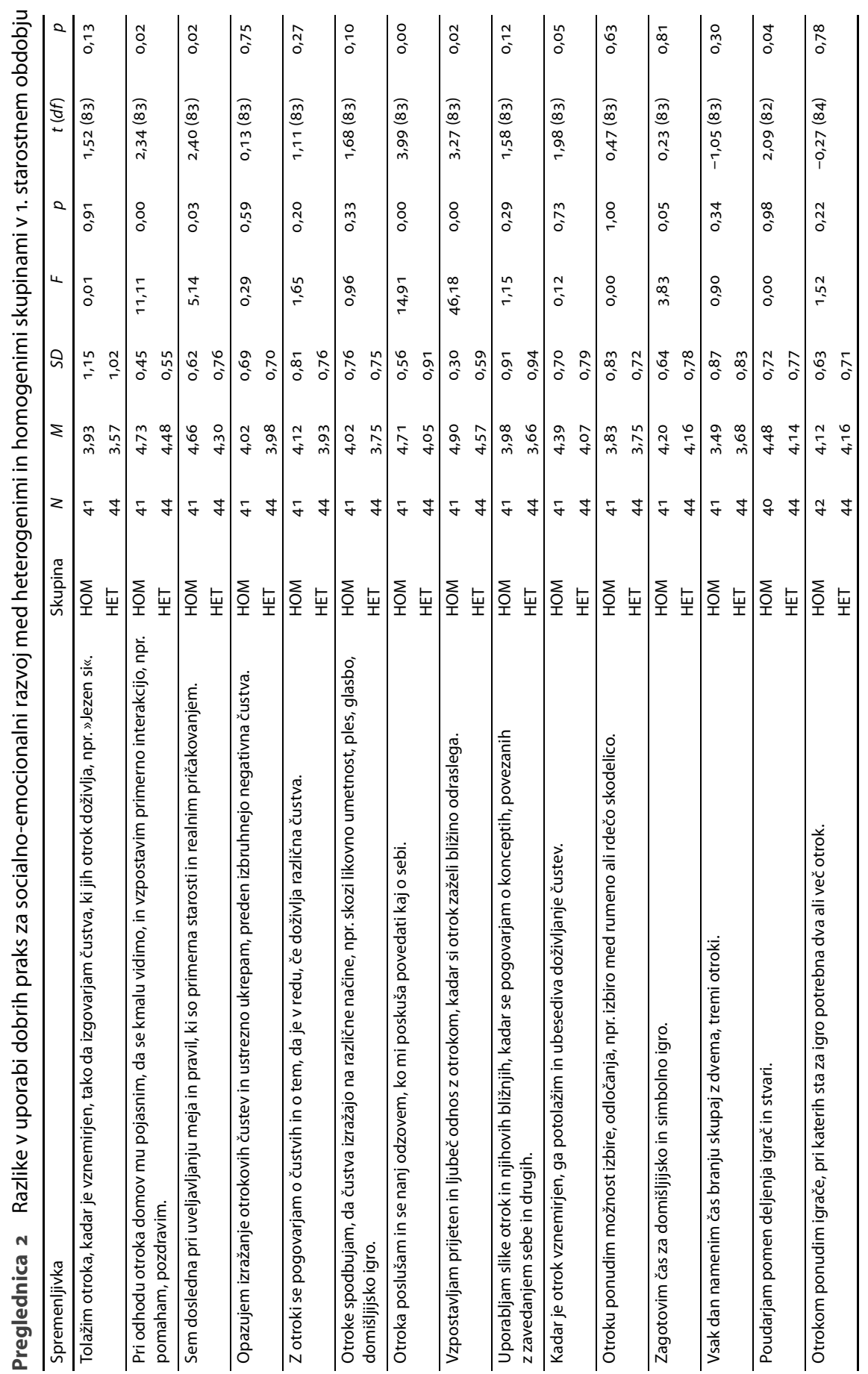


ga razvoja otrok v prvem starostnem obdobju se statistično značilno višje povprečne vrednosti pri strokovnih delavcih, ki delajo $v$ homogenih skupinah, pojavljajo pri šestih postavkah, iz česar lahko sklepamo, da delo v homogenih skupinah omogoča lažje razmere in več časa za uporabo dobrih praks, namenjenih spodbujanju socialno-emocionalnega razvoja.

\section{Razprava}

Rezultati raziskave osvetlijo nekaj pomembnih vidikov uporabe dobrih praks v 1. SO. Iz povprečnih vrednosti v sklopih a in b lahko razberemo, da strokovni delavci socialno-emocionalno področje ocenjujejo kot zelo pomembno, uvrščajo ga celo med tri najpomembnejša področja otrokovega razvoja in 1. SO glede pomembnosti socialno-emocionalnega področja razvoja prepoznavajo kot nekoliko pomembnejše v primerjavi z 2. SO, kar nakazujejo tudi druge raziskave (Rimm-Kaufmann, Pianta in Cox 2000; Durlak idr. 2011).

Nekoliko manj jasno je povezovanje področja družba $z$ učenjem in poučevanjem, povezanim s socialno-emocionalnim področjem, saj je po oceni pomembnosti strokovnih delavcev $v$ našem vzorcu $v 1$. SO področje družba šele na 4. mestu. To pomeni, da bi bilo zelo dobrodošlo, če bi bilo v Kurikulumu za vrtce (Ministrstvo za šolstvo in šport 1999) to področje bolj poudarjeno v smislu navajanja več primerov dejavnosti in ciljev, s katerimi bi strokovni delavci lahko spodbujali otrokov socialno-emocionalni razvoj ter kompetence. V Kurikulumu za vrtce (Ministrstvo za šolstvo in šport 1999) bi bilo torej treba posodobiti zapise, povezane s primeri vodenih dejavnosti, s katerimi razvijamo socialno-emocionalno področje za prvo in drugo starostno obdobje, kar bi pomenilo sistemsko podporo in poudarek na razvoju tako pomembnih veščin, podobno, kot to lahko zasledimo v tuji literaturi (Early Learning Guidelines For Children Birth to Age Three 2015).

Iz rezultatov v sklopu c lahko sklepamo, da strokovni delavci v 1 . SO v raziskovalnem vzorcu pogosteje uporabljajo dobre prakse, ki so del vsakodnevnih interakcij z otroki in zanje ni potrebno posebno načrtovanje. Manj pogosto pa izvajajo dobre prakse, za katere je potrebno vsaj delno načrtovanje (npr. skupno branje) ali pa celostno načrtovanje, kot je spodbujanje izražanja čustev skozi glasbo, ples ali likovno umetnost. Manj pogosto uporabljajo tudi specifične strategije za čustveno samoregulacijo. Zaradi tega lahko sklenemo, da bi bilo treba več poudarka nameniti strokovnemu usposabljanju glede specifičnih metod za spodbujanje, učenje in poučevanje socialnoemocionalnih veščin otrok $v 1$. SO, saj lahko tako strokovni delavci vzpostavijo bolj osmišljen sistem za razvoj socialno-emocionalnih veščin in preprečitev morebitnih težav otrok na tem področju (Powell, Dunlap in Fox 2006) 
Pri ugotavljanju razlik med homogenimi in heterogenimi skupinami smo ugotovili, da delo $v$ homogenih skupinah $v 1$. SO omogoča lažje razmere in več časa za uporabo dobrih praks, namenjenih spodbujanju socialnoemocionalnega razvoja. Morda zato, ker strokovni delavci v heterogenih skupinah ne morejo veliko časa nameniti delu s posameznim otrokom, saj so razlike med otroki večje in je potrebno veliko truda za samo vodenje skupine, zato so homogene skupine $v 1$. SO ugodnejše za otrokov socialnoemocionalni razvoj, čeprav bi bilo potrebno dodatno raziskovanje, da bi lahko ta rezultat posplošili.

\section{Literatura}

Blair, C. 2002. "School Readiness: Integrating Cognition and Emotion in a Neurobiological Conceptualization of Children's Functioning at School Entry." American Psychologist 57 (2): 111-127.

Cohen, J. 2001. Caring Classrooms, Intelligent Schools: The Social and Emotional Education of Young Children. New York: Teacher College Press.

DeVellis, R. F. 2003. Scale Development:Theory and Applications. Thousand Oaks, CA: Sage.

DiPerna, J. C., in S. N. Elliot. 2002. »Promoting Academic Enablers to Improve Student Achievement: An Itroduction to the Mini-Series." School Psychology Review 31:293-297.

Durlak, J. A., R. P. Weiessber, K. B. Schellinger, A. B. Dymnicki in R. D. Taylor. 2011. »The Impact of Enhancing Students' Social and Emotional Learning: A Meta-Analysis of School Based Universal Interventions." Child Development 81 (1): 405-432.

Early Learning Guidelines for Children Birth to Age Three: Standards, Age Descriptors, Indicators for Children, and Strategies for Interaction. 2015. Ilinois: University of Ilinois at Urbana-Champaign.

Elias, M. J., J. E. Zins, R. P. Weissberg, K. S. Frey, M. T. Greenberg in N. M. Haynes. 1997. Promoting Social and Emotional Learning: Guidelines for Educators. Alexandria: Association for Supervision and Curriculum Development.

Goodman, A., H. Joshi, B. Nasim in C. Tyler. 2015. Social and Emotional Skills in Childhood and Their Long-Term Effects on Adult Life. London: University College London.

Hyson, M. 2004. The Emotional Development of Young Children. New York: Teachers College Press.

Ivić, l., J. Novak, N. Atanacković in M. Ašković. 2002. Razvojni koraki: pregled osnovnih značilnosti otrokovega razvoja od rojstva do sedmega leta. Ljubljana: Inštitut za psihologijo osebnosti.

Joseph, G. G., in P. S. Strain. 2003. »Comprehensive, Evidence-Based SocialEmotional Curricula of Young Children: An Analysis of Efficacious Adoption Potential.« Topics in Early Childhood Special Education 23 (2): 65-76. 
Licardo, M. 2016. Razvojni mejniki jezikovnih zmožnosti, socialno-emocionalnega področja in opolnomočenje staršev za uporabo literature, iger in drugih didaktičnih sredstev: gradivo za multiplikatorje. Maribor: Pedagoška fakulteta.

Ministrstvo za šolstvo in šport. 1999. Kurikulum za vrtce: predšolska vzgoja v vrtcih. Ljubljana: Ministrstvo za šolstvo in šport.

Marjanovič Umek, L., M. Zupančič, U. Fekonja, T. Kavčič, M. Svetina, T. Ravnik, in B. Bratanič. 2004. Razvojna psihologija. Ljubljana: Znanstvenoraziskovalni inštitut Filozofske fakultete.

Payton, J. W., R. P. Weissberg, J. A. Durlak, A. B. Dymnicki, R. D. Taylor in K. B. Schellinger. 2008. The Positive Impact of Social and Emotional Learning from Kindergarten to Eighth-Grade Students: Findings from Three Scientific Reviews. Chicago: Collaborative for Academic, Social and Emotional Learning.

Petty, K. 2016. Developmental Milestones of Young Children. St. Paul, MN: Redleaf Press.

Phillips, D., K. McCartney in A. Sussman. 2006. „Child Care and Early Development. "V Blackwell Handbook of Early Childhood Development, ur. K. McCartney in D. Phillips, 471-489. Malden, MA: Blackwell.

Pianta, R. C., W. S. Barnett, M. Burchinal in K. R. Thornburg. 2009. »The Effects of Preschool Education: What We Know, How Public Policy Is Or Is Not Aligned with Evidence Base, and What We Need to Know.«Psychological Science in the Public Interest 10:49-88.

Powell, D., G. Dunlap in L. Fox. 2006. »Prevention and Intervention for Challenging Behaviors of Toddlers and Pre-Schoolers.« Infants and Young Children 19 (1): 25-35.

Rimm-Kaufman, S. E., R. C. Pianta in M. L. Cox. 2000. »Teachers' Judgements of Problems in the Transition to Kindergarten«. Early Childhood Research Quarterly 15 (2): 147-166.

Thompson, R. A., in K. H. Lagattuta. 2006. Feeling and Understanding: Early Emotional Development. Malden, MD: Blackwell.

Ward Plat, M. 2010. Moj čudežni malček: popoln vodnik po otrokovem razvoju od rojstva do 5. leta. Ljubljana: Mladinska knjiga.

Woofolk, A. 2002. Pedagoška psihologija. Ljubljana: Educy.

\section{The Use of Good Practices for Social-Emotional Development with Children Age One to Three Years in Kindergarten}

This paper presents the purpose of good practices for social-emotional development of children from one to three years. In the research we analysed the teachers' assessment of social-emotional development in comparison to other developmental areas (e. g. aesthetic development, moral ethical development, cognitive development, motoric development) and the assessment of social sciences in comparison with other subject areas of curriculum (art, science, 
language, sport, mathematics). Analysed were also differences in use of good practices among homogeneous and heterogeneous groups. Results indicate that preschool teachers who work with 1 to 3 years old children assess social emotional development as one of most important. Results also indicate that in homogenous groups ( 1 to 3 years) practices for social emotional development are used more often than in heterogeneous groups. Preschool teachers most often use practices which are part of daily interaction, less often they use practices which demand planning and knowledge about specific strategies.

Keywords: social-emotional development, methods, good practices, early childhood, preschool education 